\title{
KONSTRUKSI PENDIDIKAN ISLAM DALAM PANDANGAN HIZBUT TAHRIR (HT)
}

\author{
Oleh: Syamsul Arifin
}

Guru Besar Universitas Muhammadiyah Malang; Wakil Direktur Bidang Akademik Program Pascasarjana Universitas Muhammadiyah Malang dan Ketua Pusat Studi Agama dan

Multikulturalisme (PUSAM) pada lembaga yang sama

Email: syamsarifin@yahoo.com

\begin{abstract}
All stages of Hizb ut-Tahrir (HT) movement essentially lead to the most important stage, the Islamic law application. One of the strategic areas of HT is education. HT suggests that education should serve as a target for the Islamic law application, because as an institution related to the intent of people, it suffers from many weaknesses. HT highlight on education is directed to the paradigm on which the implementation of education system in where formal institutions is based. Weaknesses and crisis in education in the view of HT are rooted from the implemented paradigm. The paradigm meant by HT is the material-secular patterned educational paradigm. This paradigm is considered by HT to have caused the biggest crisis in education, which is the failure of education to produce humans who truly obsess a higher piety. This paper is intended to present the construction of Islamic education in the view of HT.
\end{abstract}

Keywords: Construction of Islamic Education, View, Hizb ut-Tahrir

\begin{abstract}
Abstrak
Seluruh tahapan gerakan Hizbut Tahrir (HT), pada dasarnya berujung pada tahapan yang paling penting, yaitu penerapan syariat Islam. Salah satu bidang strategis yang menjadi perhatian HT sebagai bagian dari kerangka penerapan syariat Islam adalah pendidikan. HT berpandangan, bidang pendidikan perlu dijadikan sebagai salah satu sasaran penerapan syariat Islam karena sebagai institusi yang berhubungan dengan hajat orang banyak, justru mengidap banyak kelemahan. Sorotan HT terhadap pendidikan ditujukan kepada paradigma yang menjadi dasar pelaksanaan proses pendidikan di lembaga-lembaga formal. Kelemahan dan krisis yang terjadi dalam dunia pendidikan dalam pandangan HT bersumber pada paradigma yang digunakan. Paradigma yang dimaksud oleh HT adalah paradigma pendidikan yang bercorak material-sekularistik. Paradigma ini dinilai HT telah menimbulkan krisis terbesar dalam dunia pendidikan yaitu, gagalnya pendidikan melahirkan seorang manusia yang betulbetul memiliki kesalehan yang tinggi Tulisan ini ingin menyajikan konstruksi pendidikan Islam dalam dalam pandangan $H T$.
\end{abstract}

Kata Kunci: Konstruksi Pendidikan Islam, Pandangan, Hizbut Tahrir

Naskah diterima 30 September 2012. Revisi pertama, 21 Oktober 2012. Revisi kedua, 7 Nopember 2012 dan revisi terahir 29 Nopember 2012. 


\section{PENDAHULUAN}

Hizb al-Tahrîr (HT) didirikan pada 1953 oleh Taqî al-Dîn al-Nabhânî ${ }^{1}$ di Jerusalem. Al- Nabhânî memiliki nama lengkap, Muhammad Taqî al-Dîn ibn Ibrahîm ibn Mustafâ ibn Ismaîl ibn Yusuf al-Nabhânî. Nama belakangnya, al-Nabhânî, dinisbahkan kepada kabilah Bani Nabhân, yang termasuk orang Arab penghuni padang sahara di Palestina. Mereka bermukim di daerah Ijzim yang termasuk wilayah Haifa di Palestina Utara. Al- Nabhânî dilahirkan di daerah Ijzim pada tahun 1909. Ia wafat tahun 1398 H/ 1977 M, dan dikuburkan di al-Auza'i, Beirut. Menurut Solahuddin, ${ }^{2}$ HT masuk ke Indonesia antara 1982-1983. Ini berarti sekitar 29 tahun setelah HT pertama kali didirikan oleh al-Nabhânî pada 1952.

Jika dibandingkan dengan tempat lainnya, kehadiran HT ke Indonesia bisa dibilang terlambat. Sementara di tempat lain, seperti Suriah, Lebanon, Kuwait, dan Irak, HT berkembang cukup pesat dengan rentang waktu yang terpaut pendek dari masa kelahirannya, yakni sekitar tahun 1960-an. ${ }^{3}$ Kehadiran HT ke Indonesia tidak bisa dilepaskan dari tokoh yang bernama Mama Abdullah Nuh, pengelola Pesantren al-Ghazali, Bogor, yang juga dosen Fakultas Sastra Universitas Indonesia. Pada suatu saat ia mengundang Abdurrahman alBaghdadi, seorang aktivis HT yang tinggal di Australia, datang ke Bogor membantu pesantrennya. Al-Baghdadi ${ }^{4}$ inilah yang ke-

\footnotetext{
${ }^{1}$ Penjelasan tentang riwayat hidup al-Nabhânî bersumber dari buku yang ditulis Ihsan Samârah. 1991. Mafhûm al- 'Adalah al- Ijitimâiyyah fi al- Fiqrî al-Islâmî min al Ma'âsir. Beirut: Dâr al-Nahdah alIslâmiyyah, h. 140-149.

${ }^{2}$ Solahudin. 2001. Menelusuri Kelompok Islam Sempalan (1): Mereka Dituduh Menebar Bom. http: www.detik.com.

${ }^{3}$ Suha Tahi-Farouki. 2001. "Hizb al-Tahrîr alIslâmî" dalam Eksiklopedi Oxford Dunia Islam Modern, Jilid 2, ed. John L. Esposito. Bandung: Mizan.

${ }^{4}$ Tetapi belakangan al-Baghdadi tidak aktif lagi di HT. Banyak kalangan dari luar menganggap alBaghdadi telah keluar dari HT. Sementara menurut Alwan, aktivis senior HT di Malang, al-Baghdadi me-
}

mudian menyebarluaskan gagasan HT melalui interaksi dengan para aktivis Islam di Masjid al-Ghifari, Institut Pertanian Bogor. Tidak heran, apabila HT sebagaimana kelak terjadi di Malang, memiliki basis yang cukup kuat di beberapa kampus.

Menurut catatan Dwi Hardianto, ${ }^{5}$ anggota HT di Indonesia berjumlah sekitar 10.000 orang. Jumlah anggota HT di Indonesia tentu tidak bisa dibandingkan dengan jumlah anggota ormas Islam lainnya seperti Muhammadiyah dan NU yang mencapai puluhan juta orang dan tersebar di seluruh tanah air. Namun, jumlah anggota HT yang sedikit itu di sisi lain menguntungkan bagi HT dalam melakukan konsolidasi dan pembinaan terhadap seluruh anggotanya. Terbukti HT cukup mudah memobilisasi anggotanya sehingga dalam setiap kegiatan tidak pernah sepi. Sebagai contoh, pada pertengahan tahun 2000, HT menyentakkan publik di tanah air karena berhasil menggelar Konfrensi Internasional Khilafah Islam di Jakarta. Pada tahun-tahun berikutnya, seperti yang terjadi pada Agustus 2002, HT berhasil menggelar aksi yang berskala massal berupa longmarch dari Monas ke Gedung DPR/MPR, menuntut diterapkannya syariat Islam di Indonesia.

Dalam pandangan HT, akibat runtuhnya sistem khilafah Islam pada 1924, kehidupan politik umat Islam diatur oleh sistem politik kafir (kufur). Bagi HT, runtuhnya kekhilafahan Islam merupakan pengalaman sejarah yang menyakitkan. Di samping karena umat Islam kehilangan warisan sejarah Islam yang paling berharga, yaitu sistem politik yang telah dikembangkan sejak

nyatakan tidak aktif untuk sementara waktu (mauquf) dari HT. Tetapi karena al-Baghdadi tidak memberikan batas waktu yang jelas-sampai kapan dia tidak aktif untuk sementara waktu-sehingga, menurut penilaian Alwan, bisa dinyatakan keluar. Beberapa aktivis HT di Malang tidak memberikan penjelasan secara eksplisit mengenai penyebab "keluarnya" al-Baghdadi dari HT

${ }^{5}$ Dwi Hardianto, "Hizbut Tahrir Indonesia: Dakwah Masjid yang Menggurita", Sabili No. 9 Th. XI, 142 
zaman Rasûl Allah, juga karena umat Islam semenjak berakhirnya sistem kekhalifahan mengalami krisis pada semua aspek kehidupan.

Bagi HT, seperti ditegaskan oleh Muhammad Ismail Yusanto, Juru Bicara HT di Indonesia, mendirikan daulah khilafah Islam merupakan kewajiban terbesar, dan mengabaikannya merupakan kemaksiatan terbesar. ${ }^{6}$ Sistem kekhalifahan Islam yang dikehendaki oleh HT adalah institusi tunggal yang dapat mengatur seluruh dunia Islam.

Dalam booklet berjudul, Refleksi 79 Tahun Daulah Khilafah Islamiyah yang dirumuskan HT Indonesia, dikemukakan tiga akibat yang diderita tidak saja oleh umat Islam, tapi juga oleh seluruh dunia setelah daulah khilafah Islam berakhir, yaitu: pertama, umat Islam hidup dalam kesengsaran. Kesengsaran yang dimaksud oleh HT adalah kehidupan umat Islam yang terpecah-pecah sehingga mudah dijajah oleh bangsa lain.

Kedua, dalam pandangan HT, hidup tanpa daulah khilafah Islam telah menyebabkan terlantarkannya hukum-hukum Allah terutama dalam masalah negara dan kemasyarakatan. Dampak yang harus diderita oleh umat Islam yang disebabkan tidak diterapkan hukum-hukum Islam tidak saja terjadi di bidang ekonomi dan politik. Dalam bidang pendidikan dan sosial, umat Islam juga mengalami penderitaan.

Ketiga, tidak adanya daulah khilafah Islam berakibat fatal juga terhadap perlindungan nasib kaum muslimin. Dalam pandangan HT, khalifah merupakan pelindung bagi kaum muslimin. Tapi begitu daulah khilafah Islam berarkhir, umat Islam tidak lagi mendapatkan perlindungan. Akibatnya, ungkap HT, kaum muslimin di beberapa kawasan dunia seperti Irak, Afghanistan, Chechnya, dengan mudah dikalahkan,

\footnotetext{
${ }^{6}$ al-Waie, No. 43 (Edisi Khusus), Th IV, 1-31
} Maret 2004, h. 91 bahkan menjadi korban pembantaian massal (genocide). ${ }^{7}$

Dalam pandangan HT, pendirian khilafah pada dasarnya merupakan tujuan instrumental untuk memuluskan tujuan berikutnya, yaitu penerapan syariat Islam. Ada bamyak aspek atau bidang yang menjadi sasaran penerapan syariat Islam. Salah satu bidang strategis yang menjadi perhatian HT adalah pendididikan Islam.

Tulisan ini ingin menyajikan pemikiran HT tentang pendidikan Islam. Pertanyaan pokok dari tulisan ini adalah, bagaimana konstruksi pendidikan Islam dalam pandangan HT? Dengan demikian tujuan dari tulisan ini adalah ingin mengungkap pandangan HT tentang kerangka bangun atau konstruksi pendidikan Islam.

\section{SISTEMATIKA GERAKAN HIZBUT TAHRIR}

Menyadari terhadap pentingnya pendirian kembali daulah khilafah Islam, HT telah menyiapkan strategi yang bersifat sistematis. Strategi yang digunakan oleh HT untuk merealisasikan cita-citanya ini adalah strategi yang diyakini bersumber dan dipraktekkan oleh Rasûl. Dalam buku, Bagaimana Membangun Kembali Negara Khilafah, yang ditulis oleh Shabab HT dikemukakan secara terinci strategi HT untuk mendirikan kembali daulah khilafah Islam. Strategi ini sekaligus merupakan strategi dakwah dan gerakan sosial HT.

\section{Tahapan Pembinaan dan Pengkaderan (al- Tathqîf)}

Tahapan ini menurut HT merupakan tahapan yang pertama kali dirancang oleh

${ }^{7}$ Ibid.

${ }^{8}$ Seluruh pembahasan yang berhubungan dengan strategi HT untuk mendirikan kembali daulah khilaf Islam bersumber dari: 1) Hizb al-Tahrîr, http// www.hizb-ut-tahrir.org; 2) Hizb al-Tahrîr, http:// www.geociteis.com/salafyonline/; 3) Shabab HT. 2004. Bagaimana Membangun Kembali Negara Khilafah. Bogor: Pustaka Thariqul Izzah. 
Rasûl Allah dalam mendakwahkan misi Islam kepada orang-orang di sekitarnya. Dalam pemahaman HT, Rasûl Allah, menurut HT, memberikan penjelasan tentang aqidah Islam. Ada banyak cara yang digunakan oleh Rasûl Allah dalam menjelaskan aqidah Islam. Pada suatu waktu Rasûl Allah mengundang orang-orang ke rumahnya, pada saat yang lain, Rasûl Allah yang datang. Di lain waktu, Rasûl Allah berdiskusi dengan orang-orang di pasar. Kegiatan Rasûl Allah ini dilakukan selama tiga tahun. Inti kegiatan Rasûl Allah dalam tahapan ini menurut HT ada dua: pertama, mengajak orang-orang masuk Islam melalui diskusi, bukan melalui kekerasan. Kedua, membina orang-orang yang masuk Islam dengan pemahaman yang kuat terhadap Islam dan keimanan yang kokoh dalam rangka mengemban tanggung jawab dakwah.

\section{Tahapan Berinteraksi dengan Umat (Mar- halah al-Tafâul Ma`a al-Ummah).}

Tahapan ini juga mencontoh langkah Rasûl Allah. Tahapan ini merupakan kelanjutan dari tahapan pertama yang berlangsung selama tiga tahun. Setelah dalam rentang waktu tiga tahun Rasûl Allah berdakwah secara diam-diam, pada tahapan kedua Rasûl Allah secara terang-terangan berinterasi dengan masyarakat. Rasûl Allah secara terbuka berani menantang kelemahan-kelemahan orang-orang kafir Quraish. Cara yang ditempuh oleh Rasûl Allah memang mengandung risiko. Sebab begitu dakwah dilakukan secara terbuka, Rasûl Allah mendapat tantangan keras dari para kafir Quraish.

Langkah yang ditempuh oleh Rasîl Allah tersebut juga ingin ditiru oleh HT. Dalam tahapan kedua ini, HT melakukan interaksi dengan masyarakat untuk menyampaikan pesan-pesan Islam kepada masyarakat. Target yang ingin dicapai pada tahapan kedua ini, HT berkeinginan pemikiran Islam yang telah ditetapkan oleh HT bisa diterima menjadi pemikiran umat secara luas. Jika pemikiran HT bisa diteri- ma oleh umat, maka perjuangan HT untuk mendirikan kembali daulah khilafah Islam dapat dilakukan.

Tahapan Pengambilalihan Kekuasaan (istilâm al-hukm)

Pada tahapan ini Islam, menurut HT, dapat diterapkan secara utuh. Tahapan ini dipahami oleh HT sebagai tahapan terpenting dalam sejarah perjuangan Rasûl Allah yakni ketika Rasûl Allah berhasil mendirikan negara Islam yang memiliki piagam yang sangat terkenal, Piagam Madinah. Dalam daulah khilafah Islam inilah syariat Islam dalam pandangan HT syariah Islam dapat diterapkan. Dalam pandangan HT penerapan syariat tidak boleh dengan cara gradual dan parsial, melainkan secara komprehensif.

Sebagaimana dikemukakan di muka, tahapan-tahapan yang ditempuh HT untuk menegakkan kembali khilafah juga dijadikan sebagai tahapan-tahapan dakwah HT. Dengan begitu bisa disimpulkan dakwah yang dilakukan oleh HT berujung pada tahapan pengambilalihan kekuasaan. Ada yang menarik diperhatikan dari seluruh rangkaian tersebut yakni, penggunaan kekerasan. Dalam pandangan HT, seperti dikemukakan oleh aktivis senior HT dari Surabaya, Muhammad Usman, penggunaan kekerasan sebagai tarîqah untuk mencapai tujuan dakwah tidak boleh dilakukan pada saat daulah khilafah Islam belum berdiri. Dalam keadaan belum berdirinya daulah islamiyah, aktivitas jamaah hanya dibatasi pada aktivitas fikriyah (pemikiran), yakni dengan cara menghujat dan menghancurkan pemikiran-pemikiran dan keyakinankeyakinan yang rusak dan batil. Kondisi yang dialami oleh HT sekarang ini, menurut Usman mirip dengan kondisi yang dialami oleh Rasûl Allah ketika berdakwah di Makkah, yaitu suatu kondisi di mana daulah Islam belum berdiri. Pada fase ini Rasûl Allah belum melakukan jihad dalam pengertian perang. 


\section{KONTRUKSI PENDIDIKAN ISLAM}

Salah satu bidang sosial yang menjadi perhatian HT sebagai bagian dari kerangka penerapan syariat Islam adalah pendidikan. HT berpandangan, bidang pendidikan perlu dijadikan sebagai salah satu sasaran penerapan syariat Islam karena sebagai institusi yang berhubungan dengan hajat orang banyak, justru mengidap banyak kelemahan. Berikut ini akan dipaparkan pandangan Hizbut Tahrir terhadap konstruksi pendidikan Islam yang meliputi dua hal, yakni: landasan pendidikan dan komponen-komponen pendidikan.

\section{Landasan Pendidikan Islam}

Sorotan HT terhadap pendidikan ditujukan kepada paradigma yang menjadi dasar pelaksanaan proses pendidikan di lembaga-lembaga formal. Kelemahan dan krisis yang terjadi dalam dunia pendidikan dalam pandangan HT bersumber pada paradigma yang digunakan. Paradigma yang dimaksud oleh HT adalah paradigma pendidikan material-sekuleristik. Paradigma ini dinilai HT telah menimbulkan krisis terbesar dalam dunia pendidikan yaitu, gagalnya pendidikan melahirkan seorang manusia yang betul-betul memiliki kesalehan yang tinggi. Fahmi Lukman, salah seorang Shabab HT yang juga pengurus Dewan Pimpinan Pusat Hizbut Tahrir Indonesia dalam acara Diskusi Terbatas Pendidikan Generasi bertajuk: "Membangun Generasi Cerdas, Generasi Peduli Bangsa: Solusi Tuntas Krisis Kepemimpinan Bangsa", yang diselenggarakan HTI Malang pada tanggal 18 Juli 2004 mengatakan:

“...sistem pendidikan yang materialistik terbukti telah gagal melahirkan manusia saleh, berkepribadian mulia yang sekaligus menguasai pengetahuan, ilmu, dan teknologi (PITEK). Secara formal kelembagaan, sekulerisasi pendidikan ini telah dimulai sejak adanya dua kurikulum pendidikan keluaran dua departemen yang berbeda, yakni Departemen Agama dan Departemen Pendidikan Nasional. Terdapat kesan sangat kuat bahwa pengembangan ilmu-ilmu kehidupan (IPTEK) adalah suatu hal yang berada di wilayah bebas nilai, sehingga sama sekali tak tersentuh standar nilai agama. Kalaupun ada hanyalah etik-moral (ethic) yang tidak bersandar pada nilai agama. Sementara pembentukan karakter siswa yang merupakan bagian terpenting dari proses pendidikan justru kurang tergarap secara serius. Pendidikan yang materialistik memberikan kepada siswa suatu basis pemikiran yang serba terukur secara material serta memungkiri hal-hal yang bersifat non materi. Bahwa hasil pendidikan haruslah dapat mengembalikan investasi yang telah ditanam oleh orang tua siswa. Pengembalian itu dapat berupa gelar kesarjanaan, jabatan, kekayaan atau apapun yang setara dengan nilai materi yang telah dikeluarkan. Agama ditempatkan pada posisi yang sangat individual. Nilai transendental dirasa tidak patut atau tidak perlu dijadikan sebagai standar penilaian sikap dan perbuatan. Tempatnya telah digantikan oleh etik yang pada faktanya bernilai materi juga. Berbagai tragedi pun telah mewarnai wajah dunia pendidikan kita, mulai prilaku dari siswa, mahasiswa sampai demonstrasi para guru dan pendidik lainnya yang menuntut dinaikkan tunjangan mereka merupakan kenyataan yang tidak dapat dibantah lagi, betapa dunia pendidikan kita begitu rapuhnya. Hal seperti itu dapat diperhatikan dari kejadian tawuran, curas, pergaulan bebas yang terus berulang setiap tahun".

Dalam makalah yang sama, Fahmi Lukman selanjutnya mengajukan kesimpulan permasalahan yang berkembang di masyarakat yang ia pandang sebagai akibat dari paradigma pendidikan sekuler-materialistik, sebagai berikut:

“(1) agama dipandang sebagai sesuatu yang terpisah dengan pengaturan kehidupan (sekulerisme) sehingga agama (Islam) tidak lagi berperan sebagai pengendali motivasi manusia (driving integrating motive) atau faktor pendorong (unifying factor); (2) kepribadian peserta didik mengalami keguncangan citra diri (disturbance of self image) dan kepribadian yang pecah (split personality) sehingga tidak

${ }^{9}$ Fahmi Lukman. 2004. "Potret Buram Pendidikan Kita: Tidak Melahirkan Pemimpin Ideal", Makalah Dikusi Terbatas Pendidikan Generasi Membangun Generasi Cerdas, generasi Peduli Bangsa (Solusi Tuntas Krisis Kepemimpinan Bangsa), Hizb al-Tahrir Indonesia Malang, (Malang: 18 Juli), h. 3. 
memiliki kepribadian yang Islami (al-shakhsiyah al-Islâmiyah; (3) pola hidup masyarakat bergeser dari sosial-religius ke arah masyarakat individual materialistik dan sekuler; (4) pola hidup sederhana dan produktif cenderung ke arah pola hidup mewah dan konsumtif; (5) struktur keluarga yang semula extended family cenderung ke arah nuclear family bahkan menuju single parent family; (6) hubungan keluarga yang semula erat dan kuat cenderung menjadi longgar dan rapuh; (7) nilainilai agama dan tradisional masyarakat cenderung berubah menjadi masyarakat modern yang bercorak sekuler dan permissive society ; (8) lembaga perkawinan mulai diragukan dan masyarakat cenderung untuk memilih hidup bersama tanpa nikah; (9) ambisi karir dan materi yang tidak terkendali menganggu hubungan interpersonal baik dalam keluarga maupun masyarakat."10

Kelemahan pada tataran paradigma sehingga melahirkan manusia yang jauh dari visi dan misi penciptaannya, menurut HT, semakin diperparah lagi oleh kelemahan fungsional pada tiga unsur pelaksana pendidikan, yaitu: (1) kelemahan pada lembaga pendidikan yang tercermin dari kacaunya kurikulum serta tidak berfungsinya guru dan lingkungan pendidikan sesuai dengan kehendak Islam; (2) faktor keluarga yang tidak mendukung, dan; (3) faktor masyarakat yang tidak kondusif.

Analisis HT terhadap permasalahan pendidikan yang tidak saja menyentuh aspek paradigma, tetapi juga aspek fungsionalnya, memberikan suatu gambaran bahwa HT memahami pendidikan sebagai proses dialektika antara sekolah (lembaga pendidikan formal), masyarakat, dan keluarga. HT menempatkan keluarga sebagai tempat pendidikan yang pertama dan utama. Keluarga dipandang HT sebagai institusi yang memiliki tanggung jawab besar dalam melakukan pembinaan kepribadian, meletakkan penguasaan dasar-dasar tsaqâfah Islam melalui pengajaran dan pengalaman hidup sehari-hari dan dipengaruhi oleh sumber belajar yang ada di keluarga. Oleh karena itu, HT menekankan agar institusi

\footnotetext{
${ }^{10}$ Ibid
}

pendidikan keluarga betul-betul dioptimalkan dalam mengembangkan kepribadian anak terutama melalui pembinaan aqidah, ibadah, dan akhlak. Pembinaan aqidah dipandang oleh HT sebagai langkah pertama dalam mengembangkan kepribadian anak. Sejak anak lahir sudah diperkenalkan dengan tauhid melalui kumandang suara adzan. Bahkan sejak dalam kandungan anak, menurut HT, perlu distimulasi dengan aqidah seperti melalui lantunan ayat-ayat al-Qur'ân. Pembinaan aqidah ini menurut HT perlu dilakukan secara berkesinambungan mengikuti perkembangan usia anak. Pembinaan aqidah menurut HT juga perlu dikaitkan dengan pembinan ibadah dan akhlak. Dalam keluarga anak perlu dibiasakan melakukan ibadah dan diberi teladan akhlak yang baik sebagai aktualisasi dari aqidah Islam. ${ }^{11}$

Pendidikan dalam keluarga selanjutnya dinilai oleh HT sebagai modal utama bagi kelanjutan pendidikan anak di sekolah. HT menyadari, ketika anak sudah memasuki usia lima tahun, keluarga dan masyarakat tidak lagi mencukupi kebutuhan pendidikan anak. Sekolah oleh HT kemudian dianggap sebagai institusi pendidikan yang memiliki nilai strategis karena bisa menyelenggarakan pendidikan secara berstruktur dalam suatu kurikulum. Sebagai kelanjutan dari keluarga, HT juga menekankan arti penting aqidah Islam sebagai asas pengembangan kepribadian anak didik. ${ }^{12}$

Tetapi sebagaimana dikatakan oleh HT, keluarga dan sekolah pada saat ini berada pada suatu krisis sehingga semakin memperparah dan memperluas permasalahan pendidikan yang berakar pada paradigmanya. Karena persoalan yang dialami pendidikan begitu mendasar, maka

${ }^{11}$ Hizb al-Tahrir Indonesia. 2004. "Peran Keluarga dalam Membentuk Sosok Pemimpin Dambaan Umat". Makalah Dikusi Terbatas Pendidikan Generasi: Membangun Generasi Cerdas, Generasi Peduli Bangsa (Solusi Tuntas Krisis Kepemimpinan Bangsa), Malang, 18 Juli, h. 1-4

${ }^{12} \mathrm{Ibid}$ 
penyelesaiannya, menurut HT, diperlukan perbaikan secara menyeluruh dengan cara mengubah paradigma sekuler dengan paradigma Islam. Perubahan pada tataran paradigma ini berimplikasi pula pada perbaikan di tararan strategi fungsionalnya ${ }^{13}$. Solusi yang ditawarkan oleh HT untuk memperbaiki pendidikan merupakan solusi yang melibatkan perbincangan pada aspek yang paling mendasar, yaitu filsafat.

Kegiatan pendidikan selalu membutuhkan analisis filosofis. Dalam setiap kegiatan terutama yang dilangsungkan dalam pendidikan formal selalu dipertanyakan gambaran ideal hasil pendidikan. Menjawab pertanyaan fundamental ini bukanlah pekerjaan mudah. Ia membutuhkan instrumen berfikir yang mampu menguak aspek-aspek yang mendalam tentang hasil pendidikan. Instrumen yang dimaksud adalah filsafat. Dalam konteks pendidikan, filsafat seperti dikemukakan oleh G.R. Knight, sangat bermanfaat dalam: (1) mengenal masalah-masalah dasar pendidikan; (2) memberikan evaluasi mengenai usulanusulan perbaikan terhadap masalah yang timbul; (3) memperjelas pemikiran tentang tujuan hidup dan pendidikan, (4) mengembangkan pandangan-pandangan dan program yang konsisten serta berkaitan dengan konteks secara luas. ${ }^{14}$ Dari kalangan pemikir pendidikan Islam, seperti al-Shaibanî, juga memiliki pandangan positif terhadap manfaat filsafat bagi pendidikan berupa: (1) membantu para perancang dan pelaksana pendidikan dalam membentuk pemikiran yang benar terhadap proses pendidikan; (2) memberi dasar bagi pengkajian secara umum dan khusus; (3) menjadi dasar penilaian secara menyeluruh; (4) memberi sandaran intelektual, bimbingan bagi pelaksanaan pendidikan untuk menghadapi tantangan yang muncul dalam bidang

${ }^{13}$ Hizb al-Tahrir Indonesia, "Selamatkan Indonesia"..., 23

${ }^{14}$ George R. Knight. 1982. Issues and Alternatives in Educational Philosophy. Michigan: Andrews University Press, h. 3 pendidikan, sebagai jawaban dari setiap permasalahan yang timbul dalam dunia pendidikan; (5) memberikan pendalaman pemikiran tentang pendidikan dalam hubungannya dengan faktor-faktor spiritual, kebudayaan, sosial, ekonomi, politik dan berbagai aspek kehidupan lainnya. ${ }^{15}$

Karena filsafat mempunyai kedudukan yang begitu penting, maka tidak heran jika kegiatan pendidikan selalu berawal dari perenungan-perenungan terhadap seluruh aspek yang terkait dengan pendidikan seperti tujuan pendidikan, kurikulum, metode, lingkungan pendidikan, pendidik, peserta didik, dan lain sebagainya. Seperti dikemukakan oleh Kilpatrick ${ }^{16}$ : "Philosophizing and education are, then, but two stages of the same endeavor; philosophizing to think out better values and idealism, education to realize these in life, in human personality".

Dalam perbincangan tentang pendidikan biasanya selalu dipertanyakan perspektif filsafat yang digunakan untuk mengarahkan jalannya aktivitas pendidikan. Jawaban terhadap pertanyaan ini tidak tunggal karena perspektif filsafat pendidikan yang digunakan sangat tergantung pada filsafat hidup. Oleh karana itu, seperti yang menjadi pembahasan filsafat pendidikan sebagai disiplin ilmu, perspektif filsafat dalam suatu pendidikan begitu beragam sejalan dengan beragamnya filsafat hidup. Sebagai suatu gambaran, Imam Barnadib memberikan contoh masyarakat Amerika yang memiliki setidaknya lima perspektif filsafat pendidikan yaitu: perenialisme, esensialisme, progresivisme, rekontruktivisme, dan eksistensialisme. Penjabaran dari masing-masing perspektif filsafat pendidikan tersebut sebagai berikut: (1) perenialisme menghendaki agar pendidikan kembali kepada jiwa yang menguasai abad pertengahan, karena ia telah merupakan

${ }^{15}$ Jalaluddin dan Usman Said. 1994. Filsafat Pendidikan Islam: Konsep dan Perkembangan Pemikirannya. Jakarta: Rajawali Press, h. 18

${ }^{16}$ William H. Kilpatrick. 1957. Philosophy of Education. New York: MacMillan Coy, h. 32 
jiwa yang menuntun manusia hingga dapat dimengerti adanya tata kehidupan yang telah ditentukan secara rasional; (2) esensialisme menghendaki pendidikan yang bersendikan nilai-nilai yang tinggi, yang hakiki kedudukannya dalam kebudayaan, dan nilai-nilai ini hendaklah yang sampai kepada manusia melalui sivilisasi dan yang telah teruji oleh waktu; (3) progresivisme menghendaki pendidikan yang pada hakikatnya progresif, tujuan pendidikan hendaknya diartikan sebagai rekonstruksi pengalaman yang terus-menerus, agar peserta didik dapat berbuat sesuatu yang cerdas dan mampu melakukan penyesuaian (kembali) dengan lingkungan; (4) rekonstruktivisme menghendaki agar peserta didik dapat dibangkitkan kemampuannya untuk secara konstruktif menyesuaikan diri dengan tuntutan perubahan; (5) eksistensialisme menghendaki agar pendidikan selalu melibatkan peserta didik dalam mencari pilihan-pilihan untuk memenuhi kebutuhannya masing-masing dan menemukan jati dirinya, karena masing-masing individu adalah makhluk yang unik dan bertanggungjawab atas diri dan nasibnya sendiri. ${ }^{17}$

Dengan menggunakan kerangka penjelasan di atas, bisa dimaklumi jika HT mengkritik pendidikan pada aspek filsafat atau paradigmanya. Dengan begitu, perbaikan pendidikan bisa menyentuh pada aspek-aspek yang mendasar. HT menawarkan Islam sebagai landasan filsafat untuk mengkonstruksi kembali pendidikan. HT dengan tegas mengatakan, paradigma pendidikan material-sekuleristik harus segera digantikan dengan paradigma pendidikan yang berbasis aqidah Islam. Aqidah Islam menurut HT harus menjadi dasar penentuan arah dan tujuan pendidikan, penyusunan kurikulum dan standar ilmu pengetahuan serta proses belajar mengajar,

${ }_{17}$ Imam Barnadib.1987. Filsafat Pendidikan: Sistem dan Metode. Yogyakarta: FIP IKIP, h.20. Lihat Juga Muhaimin. 2003. Wacana Pengembangan Pendidikan Islam. Yogyakarta: Pustaka Pelajar, h. 40-41 termasuk penentuan kualifikasi pengajar (guru/dosen) serta budaya sekolah yang akan dikembangkan. Dengan pilihan terhadap aqidah Islam, HT berharap krisis dalam dunia pendidikan yang bersumber dari asasnya yang sekuler segera bisa diakhiri.

\section{Komponen-Komponen Pendidikan}

Di samping membicarakan landasan pendidikan dengan aqidah Islam, HT juga membicarakan beberapa komponen yang banyak berpengaruh dalam aktivitas pendidikan terutama pada lembaga pendidikan formal. Komponen-komponen pendidikan yang dibicarakan oleh HT meliputi: tujuan pendidikan, strategi pendidikan, kurikulum pendidikan, metode pembelajaran, serta sarana dan prasarana pendidikan. Dalam buku, Menegakkan Syariat Islam, yang dikeluarkan oleh Hizbut Tahrir Indonesia (HT), pembahasan HT terhadap komponen-komponen pendidikan memang kurang begitu terperinci. Meskipun demikian, dengan melakukan pembahasan terhadap pendidikan sebagai bagian dari cakupan penerapan syariat Islam, HT bisa dikatakan memiliki kepedulian terhadap pendidikan. Apalagi masalah pendidikan ini juga memperoleh landasan hukum yang kuat karena dicantumkan dalam Rancangan Undang-Undang Dasar daulah khilafah Islam dengan jumlah pasal yang cukup banyak.

\section{Tujuan Pendidikan}

Tujuan merupakan salah satu komponen pendidikan yang terpenting. Seluruhaktivitas pendidikan sangat tergantung pada rumusan tujuan pendidikan. Atau dengan kata lain, aktivitas pendidikan terutama yang berbentuk aktivitas belajar mengajar dimaksudkan untuk merealisasikan tujuan pendidikan. Dalam tujuan pendidikan terdapat rumusan gambaran nilai-nilai ideal pribadi manusia yang ingin dilahirkan dari lembaga pendidikan. Jika tekanan tujuan pendidikan pada kualitas pribadi manusia, 
tidak berarti cakupan pendidikan menyempit pada manusia sebagai individu. Dalam kajian filsafat pendidikan seperti diungkap oleh Wan Mohd Nor Wan Daud, selalu terjadi perdebatan teoritis mengenai orientasi tujuan pendidikan. Pandangan teoritis pertama, tujuan pendidikan diorientasikan pada upaya pengembangan kualitas pribadi manusia yang meliputi aspek intelektual dan keseimbangan jiwa agar peserta didik mampu melakukan mobilitas sosialekonomi setelah menyelesaikan program pendidikan formalnya. Sedangkan dalam pandangan teoritis kedua, tujuan pendidikan lebih diarahkan pada suatu upaya pembentukan sistem sosial yang baik. ${ }^{18}$ Perdebatan teoritik seperti diungkap oleh Wan Daud itu agaknya terlalu sulit untuk dipilah-pilah jika sudah memasuki wilayah sosial yang sesungguhnya. Sebab dalam praktiknya selalu terjadi dialektika antara manusia sebagai individu dengan masyarakat. Oleh karena itu, M. Arifin, ahli kajian filsafat pendidikan Islam di Indonesia, tidak suka terhadap cara berfikir dikotomik dalam menentukan orientasi pendidikan. Menurut M. Arifin, tujuan pendidikan hendaknya diorientasikan pada pengembangan kualitas manusia dalam tiga dimensi yang mencerminkan dimensi kehidupan manusia, yaitu: (1) dimensi yang mengandung nilai dalam meningkatkan kesejahteraan hidup manusia di dunia. Dimensi nilai kehidupan ini mendorong kegiatan manusia dalam mengelola dan memanfaatkan dunia ini sebagai bekal atau sarana bagi kehidupan akhirat; (2) dimensi yang mengandung nilai yang mendorong manusia berusaha keras untuk meraih kehidupan di akhirat yang membahagiakan. Dimensi ini menuntut manusia tidak terbelenggu oleh rantai kekayaan duniawi atau materi yang dimiliki; (3) dimensi yang mengandung ni-

${ }^{18}$ Wan Mohd Nor Wan Daud. 2003. Filsafat dan Praktik Pendidikan Islam Syed M. Naquib al-Attas. Bandung: Mizan, h. 163. lai yang dapat mengintegrasikan antara kepentingan hidup di dunia dan di akhirat. ${ }^{19}$

Rumusan tujuan pendidikan dari HT rupanya juga berorientasi pada pengembangan manusia yang memiliki dimensi nilai seperti digambarkan oleh M. Arifin. Dalam Rancangan Undang-Undang Dasar daulah khilafah Islam pasal 167 dinyatakan:

“Tujuan pendidikan adalah membentuk kepribadian Islam serta membekalinya dengan berbagai ilmu dan pengetahuan yang berhubungan dengan kehidupan. Metode penyampaian pelajaran dirancang untuk menunjang tercapainya tujuan tersebut. Setiap metodologi yang tidak berorientasi pada tujuan tersebut dilarang."

Dalam pandangan HT, kedua tujuan tersebut merupakan tujuan dari aktivitas Rasûl Allah ketika mendidik kaum muslim, baik di Makkah, sebelum hijrah maupun di Madinah, pasca hijrah. Setiap orang yang dididik oleh Rasûl Allah diorientasikan agar memiliki kepribadian Islam yang agung. Mula-mula Rasûl Allah mengajak seluruh manusia untuk memeluk aqidah Islam. Baru setelah mereka beriman, diajarkan hukum-hukum Islam kepada mereka. Dengan demikian, menurut kesimpulan HT, aqidah Islam merupakan asas yang dijadikan pijakan Rasûl untuk mendidik umat Islam.

Dalam buku, al-Shakhsiyah al-Islâm, yang ditulis al-Nabhânî memberikan penjelasan secara panjang lebar yang dimaksud dengan kepribadian Islam. Menurut al-Nabhânî, kepribadian Islam di satu sisi merupakan cerminan dari dua unsur penting dalam diri manusia yaitu: pola pikir (aqliyah) dan pola sikap (nafsiyah). Kedua unsur ini menurut al-Nabhânî sama sekali tidak ada kaitannya dengan bentuk tubuh manusia, sebagai penampakan kulit luar belaka. Al-Nabhânî bahkan menilai sebagai bentuk kedangkalan berpikir jika ada sementara pendapat yang menjadikan ben-

${ }^{19}$ M. Arifin. 1987. Filsafat Pendidikan Islam. Jakarta: Bina Aksara, h. 120 
tuk tubuh manusia sebagai salah satu faktor penunjang kepribadian manusia, atau mempengaruhi kepribadian. Keistimewaan manusia, tegas al-Nabhânî, bukan terletak pada bentuk tubuhnya, melainkan pada pola pikir dan perilaku atau pola sikapnya. Kedua unsur ini memiliki hubungan yang erat, tidak bisa dipisah-pisahkan. Dalam menentukan sikap, manusia menurut alNabhânî , sangat tergantung pada pemahaman (mafâhîm) terhadap sesuatu melalui potensi akalnya. Dengan mafâhîm, manusia bisa membuat keputusan, apakah menolak atau menerima terhadap fakta yang ada di hadapannya. Mafâhîm juga, menurut al-Nabhânî, membimbing seseorang mengarahkan dorongan (muŷ̂l) dalam memenuhi naluri (gharîzah) dan kebutuhan jasmaninya. ${ }^{20}$

Poin terpenting dari al-Nabhânî, adalah pendapatnya bahwa Islam memberikan solusi dalam mengembangkan pola pikir dan pola sikap manusia. Solusi yang dimaksud al-Nabhânî adalah aqidah Islam. Dengan begitu, pola pikir seorang muslim adalah pola pikir yang didasarkan pada Islam yaitu, menjadikan Islam sebagai satusatunya tolok ukur umum terhadap seluruh pemikiran tentang kehidupan. Selama seorang menjadikan Islam sebagai tolok ukur atas seluruh pemikirannya secara praktis dan secara riil, berarti dia telah memiliki aqliyah (pola pikir) Islam. Sedangkan yang maksud dengan nafsiyah (pola sikap) Islam adalah menjadikan seluruh kecenderungannya (muŷ̂l) bertumpu pada asas Islam yaitu menjadikan Islam sebagai satu-satunya tolok ukur umum terhadap seluruh pemenuhan manusia. Selama seseorang menjadikan Islam sebagai satu-satunya tolak ukur atas seluruh pemecahannya secara praktis dan secara riil, berarti dia telah memiliki nafsiyah (pola sikap) Islam.

${ }^{20}$ Taqî al-Dîn al-Nabhânî. 2003. Al-Shakhsiyah alIslâm: Jilid I. Bogor: Pustaka Thariqul Izzah, h. 7
Tabel 1. Indikator Kematangan Kepribadian Islam

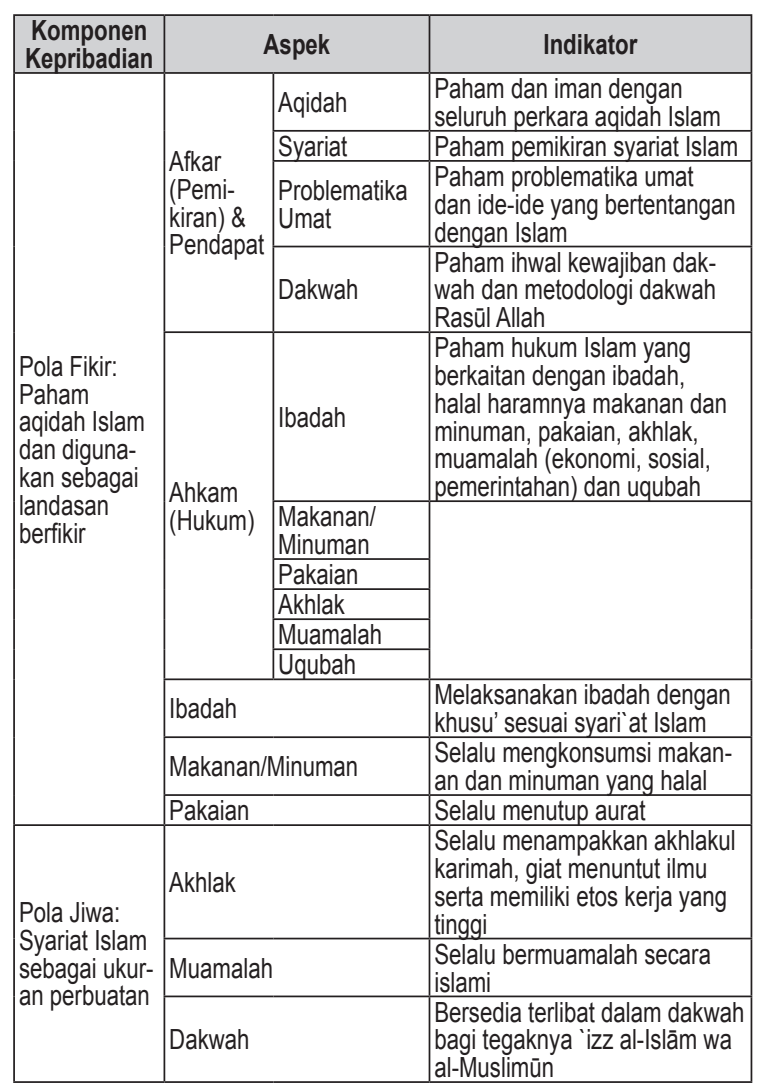

Tujuan berikutnya yang dirumuskan oleh HT berbunyi: "Membekali masyarakat dengan berbagai sains dan pengetahuan yang berkaitan dengan ihwal kehidupan mereka". Rumusan tujuan ini menarik karena seperti diketahui, sains pada saat ini di bawah dominasi Barat yang dianggap kufur oleh HT. HT sadar betul terhadap keadaan ini. Namun begitu tidak menghalangi HT mengarahkan tujuan pendidikan pada pengembangan sains. Dalam pandangan HT, sains memiliki watak universal bagi seluruh umat, tidak dikhususkan untuk satu umat saja. HT memaknai sains sebagai sebagai pengetahuan yang diambil melalui penelahan, eksperimen dan kesimpulan seperti fisika, kimia, dan berbagai ilmu eksprimental lainnya. Jika menggunakan kategori dari Ibnu Khaldun seperti juga dikutip oleh al-Nabhânî, sains dalam definisi itu disebut dengan ilmu thabi i yakni, ilmu yang diperoleh manusia melalui pemikirannya. 
Sebagai kelanjutan dari sains adalah apa yang disebut oleh HT dengan madaniyah yakni, bentuk-bentuk fisik seperti teknologi yang digunakan dalam aktivitas kehidupan. Umat Islam menurut HT diperbolehkan mengambil madaniyah dari manapun datangnya, sejauh memberikan manfaat bagi kehidupan seorang muslim dan tidak bertentangan dengan aqidah Islam. Ini berbeda dengan tsaqâfah. Jika terhadap sains dan madaniyah HT lebih terbuka. Tetapi terhadap tsaqâfah, HT bersikap lebih hatihati. HT memahami tsaqâfah seperti dijelaskan oleh al-Nabhânî sebagai pengetahuan

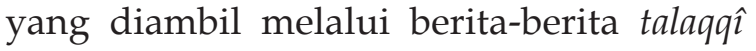
(pertemuan secara langsung) dan istinbat (penggalian dan penarikan kesimpulan) seperti sejarah, bahasa, fiqih, filsafat dan pengetahuan non eksprimental lainnya. Sifat tsaqâfah ini berbeda dengan sains yang bersifat universal. Tsaqâfah, menurut HT memiliki kekhususan karena berhubungan dengan agama dan pandangan hidup suatu kelompok masyarakat yang berbeda dengan kelompok masyarakat lainnya.

Dari kekhususan tersebut, HT kemudian memunculkan istilah tsaqâfah Islam yang kekhususannya semakin jelas karena memiliki ranah pembahasan seputar aqidah Islam dan pengetahuan yang bertumpu di atasnya seperti fiqih, tafsir, dan hadîth. Karena memiliki kekhususan, maka umat Islam oleh HT dilarang mengambil tsaqâfah sebagai pandangan hidup.

\section{Strategi Pendidikan}

Dalam setiap aktivitas pendidikan, menurut M. Arifin ${ }^{21}$, diperlukan suatu perhitungan tentang kondisi dan situasi di mana kegiatan pendidikan itu dilangsungkan. Inilah yang menjadi alasan mengapa pendidikan memerlukan srategi yang berhubungan dengan tata cara pelaksanaan kegiatan pendidikan dengan mempertimbangkan situasi dan kondisi yang ada.

${ }^{21}$ M. Arifin. 1991. Ilmu Pendidikan Islam: Suatu Tinjauan Teoritis dan Praktis Berdasarkan Pendekatan Interdisipliner. Jakarta: Bina aksara, h. 57-58.
HT menempatkan strategi sebagai suatu tata cara dalam pendidikan untuk membentuk manusia yang berkepribadian Islam. Strategi yang ditempuh HT untuk mengembangkan kepribadian Islam terdiri dari tiga langkah, yaitu: pertama, menanamkan aqidah Islam dengan metode pembuktian sesuai dengan kemampuan akal (metode aqliyah). Bukan dengan dogma atau metode-metode lain, termasuk bukan dengan metode ilmiah. Kedua, memotivasi untuk senantiasa konsisten dengan pola fikir dan pola jiwa Islam. Ketiga, mengembangkan kepribadian dengan cara mengajarkan tsaqâfah Islam, memotivasi untuk bersungguh-sungguh dalam mengisi pemikiran dengan tsaqâfah Islam dan beraktivitas dengan orientasi untuk selalu melakukan ketaatan kepada Allah. ${ }^{22}$

\section{Kurikulum}

Kurikulum juga merupakan salah satu komponen pendidikan yang terpenting. Kompetensi apa yang dikembangkan dari peserta didik, bagaimana cara mengembangkan, dan bagaimana pula tolok ukur penilaiannya, merupakan pertanyaan yang selalu muncul dalam aktivitas pendidikan. Jawaban dari pertanyaan ini terdapat dalam kurikulum. Dengan kata lain, kurikulum berisi penjelasan tentang kompetensi peserta didik yang ingin dikembangkan, metode dalam mengembangkan kompetensi, dan tata cara evaluasinya. Karena itu bisa dikatakan pula, kurikulum merupakan blue print bagi aktivitas pendidikan terutama dalam konteks kegiatan belajar-mengajar. Dengan kedudukannya yang demikian, bisa dipahami jika perbincangan seputar kritik dan pembaharuan pendidikan antara lain selalu diarahkan kepada komponen kurikulum. Di kalangan ahli pendidikan tidak

${ }^{22}$ Hizb al-Tahrîr Indonesia. 2004. "Peran Sekolah Membentuk Sosok Pemimpin Dambaan", Makalah Diksusi Terbatas Pendidikan Generasi: Membangun Generasi Cerdas, Generasi Peduli Bangsa (Solusi Tuntas Krisis Kepemimpinan Bangsa), Malang, 18 Juli, h. 1 
dijumpai adanya perbedaan mengenai perlunya tidak saja perbaikan tetapi juga perubahan kurikulum. Sadar terhadap adanya kemungkinan perbaikan dan perubahan, maka dalam pembahasan kurikulum tidak hanya difokuskan pada substansi dan sistemnya saja. Sebagaimana dikatakan Sukmadinata, pembahasan kurikulum selalu mempertimbangkan tiga karakteristik penting yang meliputi: (1) kurikulum sebagai suatu substansi yakni, bahwa kurikulum adalah sebuah rencana kegiatan belajar para siswa di sekolah, yang mencakup rumusan-rumusan tujuan, bahan ajar, proses kegiatan pembelajaran, jadwal dan evaluasi hasil belajar. Kurikulum tersebut merupakan sebuah konsep yang telah disusun oleh para ahli dan disetujui oleh para pengambil kebijakan pendidikan serta oleh masyarakat sebagai user dari hasil pendidikan; (2) kurikulum sebagai sebuah sistem yakni, kurikulum merupakan rangkaian konsep tentang berbagai kegiatan pembelajaran yang masing-masing unit kegiatan memiliki keterkaitan secara koheren dengan lainnya, dan bahwa kurikulum itu sendiri memiliki keterkaitan dengan semua unsur dalam sistem pendidikan secara keseluruhan; (3) kurikulum merupakan sebuah konsep yang dinamis yakni bahwa kurikulum merupakan konsep yang terbuka dengan berbagai gagasan perubahan serta penyesuaian dengan tuntutan pasar atau tuntutan idealisme pengembangan peradaban umat manusia. ${ }^{23}$

Konsepsi kurikulum pendidikan yang dikembangkan HT mencerminkan kerangka penjelasan di atas. HT memahami kurikulum sebagai asas yang menjadi dasar berbagai informasi yang hendak diajarkan, serta sub-sub pembahasan yang terkandung dalam informasi, beserta tata cara yang digunakan untuk menyampaikan informasi. Sedangkan cakupan kurikulum,

${ }^{23}$ Dede Rosyada. 2004. Paradigma Pendidikan Demokratis: Sebuah Model Pelibatan Masyarakat dalam Penyelenggaraan Pendidikan. Jakarta: Kencana, h. 26-27
HT menekankan pada dua penting, yaitu: materi pelajaran dan metode pengajaran.

HT juga memberikan penekanan agar aqidah dijadikan sebagai dasar penyusunan kurikulum sebagaimana dinyatakan dalam Rancangan Undang-Undang Dasar pasal 165:

"Kurikulum pendidikan wajib berlandaskan aqidah Islamiyah. Mata pelajaran serta metodologi penyampaian pelajaran seluruhnya disusun tanpa adanya penyimpangan sedikitpun dalam pendidikan dari asas tersebut"

Materi pendidikan sebagai bagian terpenting kurikulum yang didisain oleh HT meliputi dua hal yaitu: sains dan tsaqâfah. Sains meliputi seluruh pengetahuan yang diperoleh melalui metode analisis, eksperimen, dan induksi seperti fisika, kimia, teknik, matematika, industri, dan lain sebagainya. Pengajaran sains dan ilmu terapan seperti matematika dan fisika berbeda dengan pengajaran tsaqâfah. llmu-ilmu terapan dan sains diajarkan tanpa mengenal peringkat pendidikan, tetapi berdasarkan kebutuhan.

Sedangkan tsaqâfah adalah pengetahuan yang diperoleh melalui pemberitahuan, transfer, dan istinbat seperti sejarah, bahasa, filsafat atau industri yang berkaitan dengan seni- seperti gambar, pahat, dan musik. Semuanya merupakan pengetahuan spesik yang khas bagi tiap bangsa dan umat tertentu. Karena itu, tsaqâfah ini oleh HT bisa diklasifikasikan menjadi dua: Islam dan non-Islam.

Tsaqâfah Islam adalah pengetahuan yang menjadikan aqidah Islam sebagai sebab pembahasannya, baik yang mengandung pembahasan aqidah, seperti ilmu tauhid; yang dibangun berdasarkan aqidah Islam seperti fikih, tafsir, dan hadis; atau yang dibutuhkan untuk memahami hukum yang digali dari aqidah Islam seperti ilmu bahasa Arab, mustalah hadith, dan ushul fiqh. Semua ini merupakan tsaqâfah Islam. Tsaqâfah non-Islam adalah pengetahuan 
yang lahir dari aqidah non Islam sebagai sebab pembahasannya; baik dalam konteks aqidah non-Islam sebagai isi, asas, ataupun sesuatu yang dituntut oleh hukum yang digali dari non aqidah Islam. Contohnya adalah filsafat dan sejenisnya.

Tsaqâfah Islam wajib diajarkan pada semua level pendidikan. Di level universitas, hendaknya dibuka berbagai jurusan dalam berbagai cabang ilmu keislaman. Di samping itu, bisa dibuka jurusan lain, seperti teknik dan sains. Seni dan keterampilan bisa dikategorikan sebagai ilmu terapan dan sains, seperti bisnis, pelayaran, dan pertanian. Semuanya mubah dipelajari tanpa terikat dengan batasan atau syarat tertentu. Akan tetapi, di sisi lain semua itu juga bisa dimasukkan dalam kategori tsaqâfah jika telah terpengaruh dengan pandangan hidup tertentu seperti seni lukis, ukir, dan pahat. Yang terakhir ini tidak bisa dipelajari jika bertentangan dengan pandangan hidup Islam.

Sebaliknya, tsaqâfah Islam diajarkan pada tingkat sekolah dasar hingga menengah atas dengan kurikulum pendidikan yang tidak bertentangan dengan konsep dan hukum Islam. Di tingkat universitas bisa diajarkan secara utuh tsaqâfah Islam maupun non-Islam, demikian juga ilmu terapan dan sains, dengan syarat tidak menyimpang dari tujuan dan kebijakan pendidikan.

\section{Metode Pembelajaran}

Pembahasan metode yang dilakukan oleh HT tidak seperti pada pembahasan dalam ilmu pendidikan yang membahas metode secara terperinci. Secara sederhana metode bisa diartikan sebagai cara dalam menyampaikan materi. Dalam menentukan cara ini, banyak hal yang perlu dipertimbangkan sehingga sangat dimungkinkan berbagai macam metode atau cara dalam menyampaikan materi. Hal-hal yang perlu dipertimbangkan misalnya tujuan pembelajaran, peserta didik, situasi kelas, dan lain sebagainya. Banyaknya aspek yang perlu dipertimbangkan, penggunaan metode dalam kegiatan belajar-mengajar beragam. Terhadap komponen ini, HT tidak memberikan penjelasan secara detail tentang macam-macam metode menyampaikan materi. HT hanya memberikan prinsip-prinsip sebagai berikut: pertama, sesuatu harus dikaji dengan kajian yang mendalam sehingga esensinya bisa diketahui secara pasti dan sahih. Aqidah Islam, misalnya, wajib diambil dan diyakini oleh seorang muslim dengan akalnya, bukan secara dogmatis, sehingga apa saja yang berkaitan dengan asas aqidah harus dipelajari melalui aktivitas berpikir. Hukum syariat, misalnya, telah diserukan dalam al-Qur'ân dan hadîth sehingga untuk menggalinya diperlukan aktivitas berpikir yang bisa digunakan untuk memahami realitas permasalahan, nas yang relevan dengannya, serta penerapannya. Bahkan, muqallid yang awam sekalipun, ketika mengikuti pendapat mujtahid, tetap diharuskan memahami masalah yang hendak dihukumi dan hukum masalah tersebut, baru bisa mengimplementasikan hukum sesuai dengan masalahnya.

Kedua, pelajar hendaknya meyakini apa yang dipelajarinya sehingga bisa mengaktualisasikannya. Artinya, kenyataan yang dipelajarinya harus diyakini dengan bulat, jika merupakan persoalan aqidah, atau cukup diyakini dengan asumsi kuat karena relevansinya dengan fakta, jika bukan merupakan persoalan aqidah, seperti hukum dan adab. Sekalipun demikian, ia tetap wajib bersandar kepada pangkal yang diyakini dengan bulat. Dengan cara inilah, pengetahuan yang dikaji akan mendalam dan mempunyai pengaruh yang signifikan, dan mendorong setiap pelajar untuk mengaktualisasikan apa yang diyakininya. Pelajaran tersebut harus dikaji sebagai kajian praktis yang bisa menyelesaikan persoalan, bukan kajian teoretis apalagi hipotetis, sehingga obyek yang dikaji akan dideskripsikan seperti apa adanya untuk diselesaikan dan diubah. Ini akan menyebabkan 
kajian-kajian yang dilakukan dalam proses pendidikan tersebut bersifat realistis, bukan teoritis atau bahkan utopis.

\section{Sarana dan Prasarana Pendidikan}

Mengenai sarana dan prasarana pendidikan, HT mempunyai pandangan bahwa daulah khilafah Islam wajib menyediakan perpustakaan, laboratorium, dan sarana belajar-mengajar yang lain di samping bangunan sekolah dan universitas. Tujuannya adalah untuk memberikan kesempatan kepada mereka yang ingin melanjutkan penelitian dalam berbagai bidang ilmu pengetahuan dan tsaqâfah seperti fikih, ushul fikih, hadis dan tafsir; atau bidang ideologi, teologi, kedokteran, teknik, kimia, maupun sains eksperimental sehingga negara akan bisa melahirkan sejumlah mujtahid dan para saintis. Tentang kedudukan negara dalam mengatur pendidikan, HT menempatkan dalam posisi sentral seperti dalam masalah pembiayaan pendidikan yang harus ditanggung oleh daulah khilafah Islam.

\section{PENUTUP}

Seluruh tahapan gerakan HT, dasarnya berujung pada tahapan yang paling penting, yaitu penerapan syariat Islam. Daulah khilafah Islam yang juga menjadi orientasi penting dalam gerakan sosial HT ditempatkan sebagai institusi penerapan syari at. Khilafah dalam pandangan HT sebagai institusi penting yang bisa menjamin tegaknya syariat Islam. Posisi khalifah dalam insitusi khilafah memegang posisi kunci. Pendirian HT dan aktivisnya begitu kuat untuk menerapkan syariat Islam dalam suatu institusi daulah khilafah Islam. Jika ditempatkan dalam suatu perspektif studi politik, pola pemikiran yang digunakan HT adalah pola pemikiran tradisionalis dan holistik. Pola pemikiran ini memiliki pendirian kuat terhadap keparipurnaan Islam. Sebagai agama paripurna Islam memiliki tata aturan yang begitu lengkap tidak terkecuali peraturan politik yang berhubungan dengan hidup kenegaraan. Bahwa pemikiran politik HT dapat dikelompokkan dalam pola ini, bisa dicermati dari kritik HT terhadap gagasan privatisasi agama dalam buku berjudul, Menegakkan Syariat Islam, yang ditulis oleh tim HT Indonesia. Gagasan privatisasi agama dalam pemahaman HT adalah gagasan yang menempatkan agama dan negara sebagai dua institusi terpisah. HT menolak tegas gagasan ini. HT justru berpendapat sebaliknya, antara agama dan negara tidak saja dapat dipertemukan bahkan bisa disatukan. Dalam unifikasi ini agama menurut HT dapat berdiri dalam posisinya sebagai asas yang mensuplai seluruh pemahaman, standarisasi, dan keyakinan yang akan dijalankan oleh negara. Tentu saja, dalam pandangan HT Islam bisa mengambil posisi seperti ini karena Islam merupakan agama yang mengajarkan aspek rûhiyyah (keakhiratan) dan siyâsiyyah (keduniaan). Islam bukan hanya agama, tetapi juga ideologi. Demikian juga dengan syariat yang menjadi perjuangan HT untuk diterapkan termasuk di Indonesia, cakupannya sangat luas. Syariat Islam, tegas HT, bukan hanya mengatur urusan dan persoalan keyakinan spiritual ('aqîdah rûhiyyah), melainkan juga ideologi politik ('aqîdah siyâsiyah). Dalil yang digunakan HT untuk memperkuat pendiriannya itu adalah firman Allah: "Kami telah menurunkan al-Kitâb (al-Qu'rân) ini kepadamu (Muhammad) untuk menjelaskan sesuatu" dan "Hari ini Aku telah menyempurnakan untuk kalian agama kalian, telah mencukupkan nikmatku untuk kalian, dan telah meridai Islam sebagai agama kalian".

Dengan cakupan syariat Islam yang luas itu, Islam menurut HT merupakan agama yang tidak bisa disamakan dengan agama lain seperti Kristen, Yahudi, Hindu, dan Budha. Dalam analisis HT, agamaagama tersebut hanya menekankan pada dimensi spiritual saja sehingga hanya bisa disebut sebagai agama. Ini berbeda dengan Islam. Di samping disebut dengan agama, juga disebut dengan ideologi. Tetapi HT mengingatkan, meskipun Islam disebut 
sebagai ideologi-di samping sebagai agama-Islam tetap memiliki distingsi dengan ideologi seperti kapitalisme dan sosialisme. Kedua ideologi ini dalam tinjauan HT hanya membahas persoalan keduniaan semata. Perbandingan yang dibuat HT antara Islam dengan agama-agama dan ideologi-ideologi lain di dunia pada dasarnya HT ingin menempatkan Islam sebagai satu-satunya aturan hidup yang unggul, sempurna dan paripurna, sehingga hanya Islamlah yang dapat ditempatkan sebagai agama dan ideologi sekaligus. Antara Islam dan ideologi ini dipandang HT memiliki perbedaan mendasar. Dalam hal produk hukum yang dilahirkan dari kedua ideologi ini jelas tidak bisa disamakan dengan Islam. Dalam Islam, jelas HT, nas-nas syari`at merupakan sumber-sumber hukum yang dengannya realitas disesuaikan. Dalam Islam, hukumhukum syari at tidak bisa berubah meskipun realitas mengalami perubahan.

HT juga menolak perbedaan budaya bisa dijadikan faktor determinan yang dapat mengubah hukum-hukum Islam. Bagi HT, budaya tidak memiliki kekuatan untuk mengubah hukum karena bukan `illat (motif diberlakukannya hukum) dan sumber hukum. Apalagi dalam analisis HT, banyak produk budaya yang justru bertentangan dengan syari'at. Sebagai konsekuensi dari pendapatnya ini, HT nampak hati-hati dalam menggunakan prinsip kemaslahatan yang sering juga dijadikan pijakan dalam menentukan hukum suatu persoalan. Dasar pertimbangan utama yang digunakan oleh HT dalam menentukan kemaslahatan suatu perkara tetap syari at, bukan akal. HT meragukan kemampuan akal dalam menentukan substansi kemaslahatan. Hanya Allah yang dipandang HT dapat menentukan substansi permasalahan. Karakteristik hukum seperti ini tidak dimiliki oleh ideologi kapitalisme dan sosialisme. Berbeda dengan Islam, kapitalisme dan sosialisme hanya menjadikan realitas sebagai pertimbangan hukum. Akibatnya, hukum produk kapitalisme dan sosialisme berubah-ubah dari waktu ke waktu dan berbeda-beda antara satu tempat dan tempat lainnya.

Dengan demikian, konstruksi HT tentang pendidikan Islam sebagaimana dibahas pada artikel ini, perlu diletakkan dalam konteks keyakinan keagamaan, ideologi dan gerakan HT tersebut. Tentu saja, pandangan HT tersebut terbuka untuk dikritik.

\section{SUMBER BACAAN}

Arifin, M (1987): Filsafat Pendidikan Islam. Jakarta, Bina Aksara.

Arifin, M (1991): Ilmu Pendidikan Islam: Suatu Tinjauan Teoritis dan Praktis Berdasarkan Pendekatan Interdisipliner. Jakarta, Bina aksara.

Barnadib, Imam (1987): Filsafat Pendidikan: Sistem dan Metode. Yogyakarta, FIP IKIP.

Daud, Wan Mohd Nor Wan (2003): Filsafat dan Praktik Pendidikan Islam Syed $M$. Naquib al- Attas. Bandung, Mizan.

Hardianto, Dwi., "Hizbut Tahrir Indonesia: Dakwah Masjid yang Menggurita", Sabili, No. 9 Th. XI, 142

Hizb al-Tahrir Indonesia (2004): "Peran Keluarga dalam Membentuk Sosok Pemimpin Dambaan Umat", Makalah Dikusi Terbatas Pendidikan Generasi: Membangun Generasi Cerdas, Generasi Peduli Bangsa (Solusi Tuntas Krisis Kepemimpinan Bangsa. Malang, 18 Juli.

Jalaluddin dan Usman Said (1994): Filsafat Pendidikan Islam: Konsep dan Perkembangan Pemikirannya. Jakarta, Rajawali Press.

Kilpatrick,William H (1957): Philosophy of Education. New York, MacMillan Coy.

Knight, George R (1982): Issues and Alternatives in Educational Philosophy. Michigan, Andrews University Press. 
Lukman, Fahmi (2004): "Potret Buram Pendidikan Kita: Tidak Melahirkan Pemimpin Ideal", Makalah Dikusi Terbatas Pendidikan Generasi Membangun generasi Cerdas, generasi Peduli Bangsa (Solusi Tuntas Krisis Kepemimpinan Bangsa), Hizb al-Tahrir Indonesia Malang. Malang, 18 Juli.

Muhaimin (2003): Wacana Pengembangan Pendidikan Islam. Yogyakarta, Pustaka Pelajar.

Mughni, Syafiq A (1997): Sejarah Kebudayaan Islam di Turki. Jakarta, Logos.

Al-Nabhânî , Taqî al-Dîn (2003):al-Shakhsiyah al-Islâm: Jilid I. Bogor, Pustaka Thariqul Izzah.
Rosyada, Dede (2004): Paradigma Pendidikan Demokratis: Sebuah Model Pelibatan Masyarakat dalam Penyelenggaraan Pendidikan. Jakarta, Kencana.

Solahudin (2001): Menelusuri Kelompok Islam Sempalan (1): Mereka Dituduh Menebar Bom. http:www.detik.com/peristiwa/2001/01/10

Tahi-Farouki, Suha (2001): "Hizb al-Tahrîr al-Islâmî" dalam Eksiklopedi Oxford Dunia Islam Modern, Jilid 2. Ed. John L. Esposito. Bandung, Mizan.

Wajdi, Farid (2004): “Amal Politik Partai Islam", al-Wa ie, No. 47 Th. IV, 1-31 Juli. 